\title{
The Art to End All Arts
}

\section{Claes Entzenberg}

\begin{abstract}
A в STR Aст The death of art has been a notion used in connection with the development and progress of art. This view of the development of art, the movement from one position to another, can go on forever. From another view, we see art as part of a narration, which makes the death of art absolute and final, even though art is still produced (Hegel's version). In our time, the American philosopher A.C. Danto uses Hegel's developmental view on history to explain pictorial Western art from the Renaissance up until now. In Danto's philosophy of art, the final end means that a certain theory of art ends; the development of the theory of art as a sensuous object cannot be developed further. I agree that something happens during the 60 s that is extremely important. But what happens is that old systems evaporate and pluralism enters the art scene. To understand this new scene we must give up old grand systems, and see the theory-boundedness of the practices of art we meet today. Yes, this death concerns grand theories, and, by no means, art as theory.

KEYWORDS Danto, The end of art, theory, pluralism
\end{abstract}

The sense of ending is troublesome. But the experience is common enough to be familiar to everyone. From the art scene, the Dada movement in Berlin early in the 2oth century wrote "Die Kunst ist tot - es lebe die Kunst" [Art is dead, long live Art] on posters for photomontage, and in a similar spirit the famous French Fluxus artist, Robert Filliou, writes during the sixties that "Lart c'est ce qui rend la vie plus intéressante que l'art" [Art is that which makes life more interesting than art]. These statements are significant for the demands for a renewal of the art scene, and traditional art is seen as having in some sense exhausted its possibilities. The abolishing of traditional art and the celebration of the new in the first example is repeated in the second with the exception that the new art here is now challenging what was once new, the development of the modernist effort to claim the autonomy and self-sufficiency of art is now replaced with the effort to return to life through art. In both examples, art is seen as being revitalized by new elements, not something that will stop developing and finally demise. The logic of avant-garde is still running, the belief in innovation and development of the art tradition, the idea that some art is ahead of the tradition, and still part of the developmental history of art.

\section{End as Development in History or as the Closure of History}

Things die off in various ways: they wear out, dissipate into triviality, and prevent progress. Some will argue that art in our time has succumbed to all three of these. Instead of guessing when the actual event or the 
onset of the disease began, starting with Duchamp's 'ready-mades' or Kandinsky's non-objective expressionism (both of which emerged during World War 1) and continued/developed with/through Pop Art, Conceptualism, Performance, and various forms of ideological art in the sixties, we confront what at least might appear to be a paradox: Why are art disciplines experiencing such growth of diverse artworks simultaneously as it is proclaimed dead by certain writers? There are more artists working today, more art-schools, galleries, museums than ever before in history. Since all these disciplines continue regardless of their proclaimed end, it can be assumed that the end of art is an occasion for something else. A distinction between the death of art in history and the death of art history is necessary. According to the former, it is not about the death of art as a genre or as an artistic discipline. It is about the end of a certain art, or one type of theory of art that gave the artworld its institutional, artistic legitimacy. So, according to this notion of 'deaths' and 'ends' of theory and artistic categories, the need to speak and write on death comes from a need to define 'new art' or significant changes that are running in history. According to the latter, our common theory of art that we have had for hundreds of years, the artwork as a sensuous form providing feelings, cannot be retained. The development of this narrative along this line of thinking evaporates. ${ }^{1}$ So, the death of art may be said to be the point at which art continues to exist in history, but the narrative end of art as a sensuous object must come when philosophy takes over. Art can reach its final end (after its history has ended when initial questions are answerable by philosophy from the demonstration of art). In terms of specific sensuous forms and feelings, reach a point were the development is impossible (art cannot be philosophy). The linear view of the history of art must be replaced. If art stops, then the theory cannot continue. If theory stops, then art cannot continue. The search for an ultimate theory of art is over. Art history must take on a new shape, according to which we have a battle among theories that fight for precedence within cultures. The ultimate death concerns, thus, only the death of a certain sensuous view of art, the narrative line that dominates theory (grand theory). History might not offer this kind of narration again.

\section{Art comes to an End (as progress of the sensuous)}

In this paper, I will discuss the "End-of-Art" thesis in connection with the famous American philosopher and art critic, Arthur C. Danto's After the End of Art: Contemporary Art and the Pale of History (1997). ${ }^{2}$ I will end up with a modified theory of Danto's position with some help from his 
earlier works. Transferred to the history of art, Danto argues that Hegel's developmental point-of-view on history can explain the progress of (pictorial) 'Western' art from the Renaissance up until now. What is obvious in Danto's account is that a certain narration ends when art no longer is understood as a sensual object for feelings. After Warhol's exhibition of Brillo and imitations of other commercial products something ends during the 1960 s to be followed by plural positions (post-historical art), making one narration impossible because we have unaccountable varieties. Something happens during the 6os that makes the old linear thinking of art history unusable and this change seems permanent.

Let's return to Hegel and his placing of the end of art among the efforts of his contemporary art to transgress art to be philosophy (a necessary step according to Hegel). Even if Hegel usually has been seen as the philosopher behind this rumour in Europe, ${ }^{3}$ he never explicitly states that art has ended and died. But it is not difficult to see that his developmental view on the history of the mind is applicable to the 'end-of-art' thesis: "Art, considered in its highest vocation, is and remains for us a thing of the past", stated Hegel in his Vorlesungen über die Ästhetik, delivered in 1828 , and published posthumously in $1831 .^{4}$ It is not primarily a thesis about art so much as a thesis regarding our relationship to it. It is a thesis about human beings, whose progress in self-understanding means that we can never again relate to art as our predecessors did. Art is a product of thought (Mind, Spirit, Geist). It works by sensuous means; our mind has risen above and beyond what art is capable of. Art belongs to a less evolved mode of thinking than what the mind, not only ideally but also actually, is capable of - and we find this higher capability of self-reflectiveness only in philosophy. The three manifestations of art (symbolic, classical and romantic) are different levels of the spirit's development: when we move to the next level, we leave the level of sensuous manifestations of the spirit. Art belongs to a less evolved mode of thinking: it belongs to an earlier phase of development of the mind to unconstrained flight and freedom. But Hegel needs only progression and posits a goal: events are included (selected) in the story inasmuch as they contribute to the realization of the goal. And if and when such a goal is achieved, the story - as a progressive, developmental narrative - is over.

Hegel can be accused of misunderstanding the art of his own 'now' (roughly the 1820s when he gave his lectures on art). As we all know, art, even great art, as regards its highest possibilities, was produced then and has been produced ever since. We acknowledge that he is not talking about a similar empirical situation but an historical necessity, a progres- 
sion following the structure of the genre of the Bildungsroman, where the spiritual journey to self-awareness, in Hegel's thinking, goes through three stages: art (mind is manifested sensuously), religion (mind is manifested through icons and symbols), and philosophy (mind is manifested through self-knowledge). Art has also evolved through these three stages, of which the classical phase marks the highest level of art as art. Once this final stage had been reached (during Hegel's lifetime), art could be viewed as completing its evolution and would cease to develop further. This progress could not be falsified by examples of (great) art after the end of art. Arthur Danto's thoughts, when proposing the theory of the death of art, stem from this notion of history.

The idea of a final end is then difficult to apply even to Hegel's time, and so is the notion that art can be "born of the spirit and born again", as Hegel wrote ("Aus dem Geiste geborene und wiedergeborene"). ${ }^{5}$ Curtis L. Carter writes: "If one regards dialectic as the key element in Hegel's understanding of the evolution of culture, the system remains open to the possibility of unending change". ${ }^{6}$ Hegel's view on the task of describing the mind of philosophy is an eagle eye that discerns direction, following the road that the mind takes to new levels by the process of "Aufhebung" (both erasing and moving upward). The spiritual travel from art to philosophy is a journey home, purifying the mind from matter, whose progression follows a one-way street. The difficulty with Hegel's developmental view of history is how to understand our contemporary interest in earlier art, how to bridge the gap between the mind of art and later stages of the mind's development towards philosophy (of art). Art(mind) is always separated from philosophy(mind) and cannot be exceeded, without disintegration and chaos (that we have on the cultural scene from the 6os, where struggles for dominance was continuous). But must not these borders necessarily be exceeded when we try to understand previous stages of mental developments? My alternative is a story that encompasses a multitude of historical narratives that closes chapters of the history of art, but that does not shut the book. Theory disseminates into theories. For eventually, artists find other projects to pursue, and at least some of them are developmental. The deaths of art only reflect a loss of a dominating master narrative. If we ever experience it, the logic of avant-garde, we appear less likely to find it warranting to understand the art scene after the 6os and especially today. ${ }^{7}$ 


\section{Danto and the Theory of Art and its Narration}

Danto equates avant-garde art with non-verbal painting. In 1964, Andy Warhol presented his Brillo boxes among other commonplace objects by appropriating the exact appearance of an actual mass-produced non-art object. Warhol carried his consumer-product imagery into the realm of sculpture. Calling to mind a factory assembly line, Warhol employed carpenters to construct numerous plywood boxes identical in size and shape to supermarket cartons. With assistance from others, he painted and silkscreened the boxes with logos of different consumer products: Kellogg's corn flakes, Brillo soap pads, Mott's apple juice, Del Monte peaches, and Heinz ketchup. The finished sculptures were virtually indistinguishable from their cardboard supermarket counterparts. First exhibited at the Stable Gallery, the room was piled high with boxes that recalled a cramped grocery warehouse. Though they did not sell well, they caused much controversy because they had a certain mundane, commercial subject matter that infuriated the critics. ${ }^{8}$ What Warhol demonstrated was that when defining art, we, if following the old narrative, look in the wrong place, and as Danto writes, the demonstrated answer to this question (what is the appearance of art?) is negative: we cannot decide with reference to sensuous qualities what is art and non-art: we need conceptual, contextual knowledge to decide how to identify something as art. As Danto famously writes, "To see something as art requires something the eye cannot descry - an atmosphere of artistic theory, a knowledge of the history of art: an artworld". 9

Art and non-art are perceptually indiscernible (art semblance, artistic transfiguration is thus real and not real). He points out the creation of an extended cultural platform for young people exclusively, generating antimodernist positions that open up the integration of everyday, political and social aspects (in several forms of music, literature, dance, film, etc). ${ }^{10}$ According to Danto, if art is no longer visually identifiable, then nearly all of the previous attempts to define art historically have fallen short. The exhibition of commonplace objects places the ontological question (What is art?) in philosophical receivership. The philosopher can now finally answer the question of the essential nature of art outside history. Danto writes,

I was writing about a certain narrative that had, I thought, been objectively realized in the history of art, and it was that narrative, it seemed to me, that had come to an end. A story was over. It was not my view that there would be no more art, which "death" certainly implies, but that whatever art there was to be would be made without the benefit of a reassuring sort of narrative in which it was seen as the appropriate next stage in the story. ${ }^{11}$ 

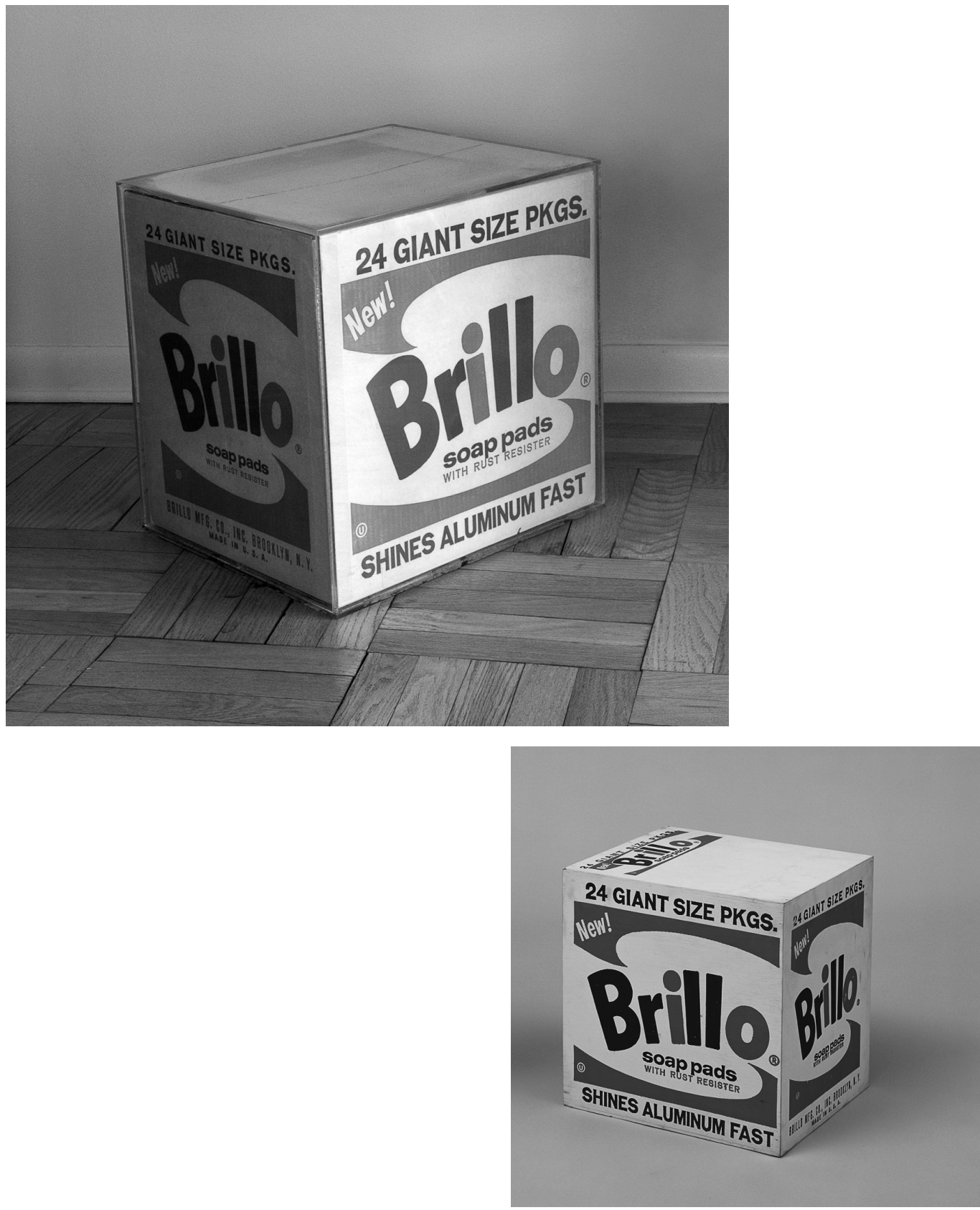

James Harvey, Brillo Box. Photo: Nialla Photos Inc. ${ }^{12}$

Andy Warhol, Brillo Box (Soap Pads), 1964. ( 2012. Digital image, The Museum of Modern Art, New York/Scala Florence. $^{13}$ 
This is the story that Danto wishes to tell in After the End of Art: How history can come to an end, what it means to say that art history is over, and why this can be regarded as a good thing. When Danto speaks of art, he means a certain developmental history of art. In his historical account, events are connected in a narrative that goes beyond simple temporal ordering: there is a beginning that gives rise to complications that needs closure. So, when Danto says that the history of art is over, he means that a certain development - a certain narrative development - is done. Artworks will still be created: what is over is a particular linear developmental narration, giving order to art history. This happens, for example, in art history when, in the nineteenth century, photography and cinema perfected the mechanical to render appearance accurately. ${ }^{14}$ The story is still being told, but this story is (for all intents and purposes) over.

If this story closed one narrative in the history of art, new events will be established. In modernism, art becomes the project of self-definition. Insofar as art history has a determinate structure, the project of self-definition had a developmental structure, and presumably, the project could be brought to completion. And this happens, Danto writes, when Andy Warhol demonstrates that art has moved beyond the box. He writes "The artist have made the way open for philosophy and the moment has arrived at which the task must be transferred finally into the hands of philosophers". ${ }^{15}$ Warhol has advanced the plot as far as he can, and the art history as a progressive linear narrative comes to an end, or, at least, a stopping point. But can we understand history as a progressive linear story that now is over?

If we accept the idea that a certain developmental history of art is ended as early as in 1964, most of the art produced in the 'West' belongs to art "after the end of art" (though one would be relieved if some of it did). One must feel uncomfortable with the idea that most of what is viewed as contemporary art, will be 'post-historical', belonging to the epilogue of the story of art. Instead, we have a positive side (mentioned by Danto): we live in an extremely fertile time, where there is no tap on creativity and the speed of development is high and complex. What happened during the later period of the 2oth century is that we cannot explain art by reference to one developmental narration of art's self-definition. What the artists end is the belief that the history of art follows this progressive narrative that can end. And this narrative lies in ruins since the 1960s and we witnessed even then a severe critique of this view of history and art. Several particular theories exist with their 
own narration fighting for precedence over one another. The master narrative of the history of art accepted by generations of scholars was finally understood as an accepted and dominating construction of the history of art. ${ }^{16}$

Other engines besides art's self-definition are governing art history, this being only one of several today. ${ }^{17}$ So, the late part of the 20 th century ended with tolerance of pluralism that amounted to the tacit confession that there was no single direction to speak of. And this makes art rather strange and unpredictable. I can illustrate this with a situation when the caretaker at an art museum finds a bag of trash on the floor. The artistic identification demands a theory (knowledge about the relevant one, because comparing objects will not do) and if the caretaker doesn't know, he had better leave the bag where he found it. The Guardian tells a telling story in 2001 about what happened when the artist Damien Hirst presented an untitled installation at the Eyestorm Gallery, a west London gallery. ${ }^{18}$ It looked like the remnants of a party; the piles of full ashtrays, half-filled coffee cups, empty beer bottles and newspapers strewn across the gallery. And this is what it was. Hirst has arranged this rubbish into an impromptu installation, which increased its value by thousands. So, the next morning when the cleaner arrived for work, he decided to clean up the mess by putting it all in trash bags. The cleaner explains: "I didn't think for a second that it was a work of art - it didn't look much like art to me". Staff were dispatched to find the trash bags in the trash and to reconstruct the installation from photographs taken earlier. Damian Hirst said that the piles of junk represented an artist's studio and said that the mistake was "fantastic". Friends of traditional skills of drawing and painting praised the cleaner's action. A critic writes, "The cleaner obviously ought to be promoted to an art critic of a national newspaper. He clearly has a fine critical eye and can spot rubbish". The object is clearly not enough to tell what it is. The identification demands both theory and history of art: it is contextual.

Now when the difference between art and non-art is not perceptual, a commonplace assumption in culture since the birth of the art system in the 18th century cannot be used. A new receiver is needed, one that has knowledge about contemporary art and actual works of individual creators. The overcoming of boundaries between art and life, gender gaps, political and social gaps places art in the spirit of pluralism. I think that this is the beginning of a new story that avoids certain agony, earlier related to its work with the essential difference between the medium of 
The Art to End All Arts

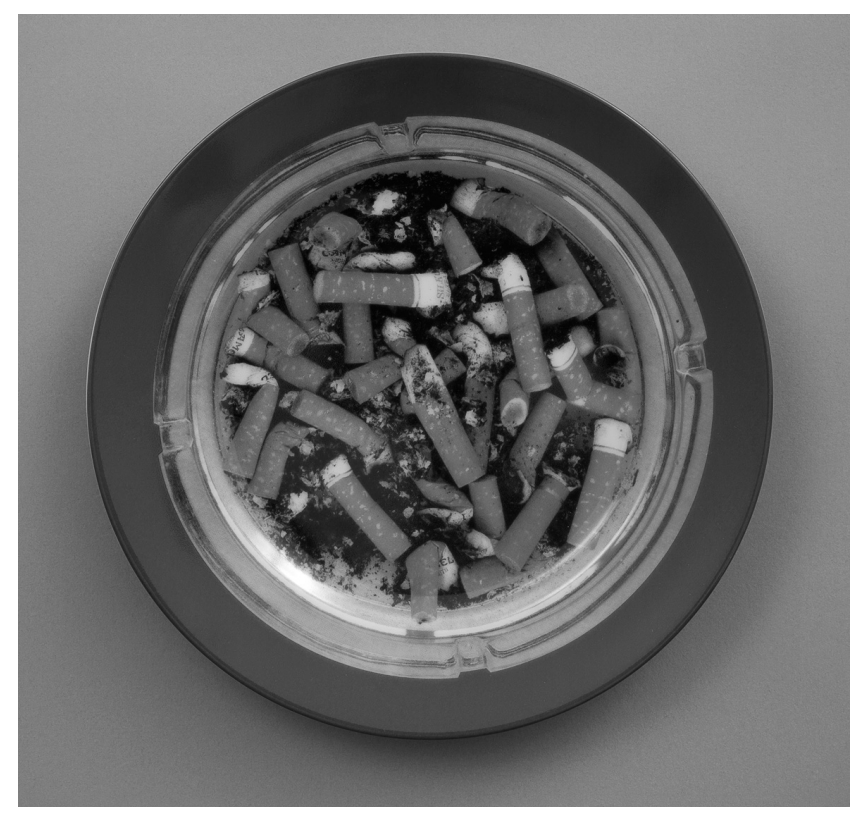

Damien Hirst, Home Sweet Home, 1996. @ 2012. Digital image, The Museum of Modern Art, New York/Scala, Florence. $^{19}$ 
art and what's outside. But Danto's account is doing more than illuminating what has happened. It predicts the future. Art history will never be developmental and linear again.

\section{To Accept the Challenge of Pluralism}

In Danto's The Transfiguration of the Commonplace (1981) it is emphasized that artistic identification requires art theories: Art is dependent upon theory for its very existence. Theory is, Danto writes, "so powerful a thing as to detach objects from the real world and make them part of a different world, an artworld, a world of interpreted things" ${ }^{20}$ As Danto conceives of art theory, it determines how the 'is' of artistic identification functions. Contextualization of an object governs the identification. The object's features are no longer enough to tell what it is (dematerialization): we have to replace contemplation and distance with knowledge, sometimes very situated and particular. If Danto is correct, developmental narratives will no longer be possible. The backbone of art history is the developmental story, in which, for example, impressionism leads to cubism and on to abstract expressionism. ${ }^{21}$ Many, outside or inside academic circles, complain about a linear art history, but few propose an alternative. Since a linear history is easy to conceptualize, is pervasive, suggests inevitable outcomes, and is therefore an excellent sales tool, it dominates discourse. The traditional image is linear, a one-way street. Today, we have rather a freeway with overpasses and underpasses going in multiple directions. In reality, all roads do not lead to the gallery, museum, and history. Re-conceptualizing art history is not to view it as post-historical but poly-historical, to see history as interwoven stories. The philosophical difference between art and non-art is contextual, making room for difference of various appearances.

As has been pointed out, Danto, in After the End of Art, does not make use of the artworld theory (suggesting perhaps that Danto himself has now come to abandon it). ${ }^{22}$ Danto provides two conditions for art here - "aboutness" and "meaning-embodiment" which lead to difficulties to differentiate between real things and art and between indiscernibles (as, for example, appropriations of other artworks). As early as in The Philosophical Disenfranchisement of Art (1986), he claims the following, in the chapter "The End of Art": "The age of pluralism is upon us. It does not matter any longer what you do, which is what pluralism means. When one direction is as good as another direction, there is no concept of direction any longer to apply." ${ }^{23}$ So, analogously, we can say 
that when one theory is as good as another theory, there is no concept of theory any longer to apply. Now, when lacking a master theory in the age of pluralism, we have to get along without it. The theory is vital here (whether or not we realize this perspective and even if we understand "theory" to mean nothing more than 'seeing as'), it becomes or stays plural. As Danto puts it in his article "The Artworld", "It is the role of artistic theories, these days as always to make the artworld, and art, possible". ${ }^{24}$ While I think it is true, it needs to be developed further to be explanatory today. The artworlds have changed when the progressive master theories ended and the artworlds and theories took a new turn, without a dominating theory. As long as the history of many things we call 'art' stays alive, we can bring art back to where it belongs, as a vehicle for many positions and human ends that govern its encounters. We have to live with discomforting pluralism in the artworld and this makes things more difficult, now living without one identity-giving theory. Art is, paradoxically, more theory-bound than before, and now we have a multitude of theories that we only can pay homage to as they express the 'objective spirit' of our time. What we see today is the use of several theories that are forced into constant flux. One aspect of the plurality is that something so vaguely defined could ever be definitely ended. The existing contemporary era of art examines this construction of a master theory and appears to have collectively decided that it is no longer beneficial for understanding the practice of art.

But the lack of a master theory does not prevent new stories to develop and news turns to be grasped. Charles Lutz's work Momento Mori [Remember you must die, 2010] becomes a counterpart to Rauschenberg's Erased de Kooning Drawing (1953), and becomes a complex break with the theory behind Pop art. But the axe here can be understood as pointing to something complex and ambivalent: as both part of a liberation of new art from old ideals of art and a savior of the idea that art is not a sensuous object, is not something the axe can end. To finish with one of Charles Lutz' masterpieces is to point out that stories continue now and hopefully forever: $:^{25}$ 


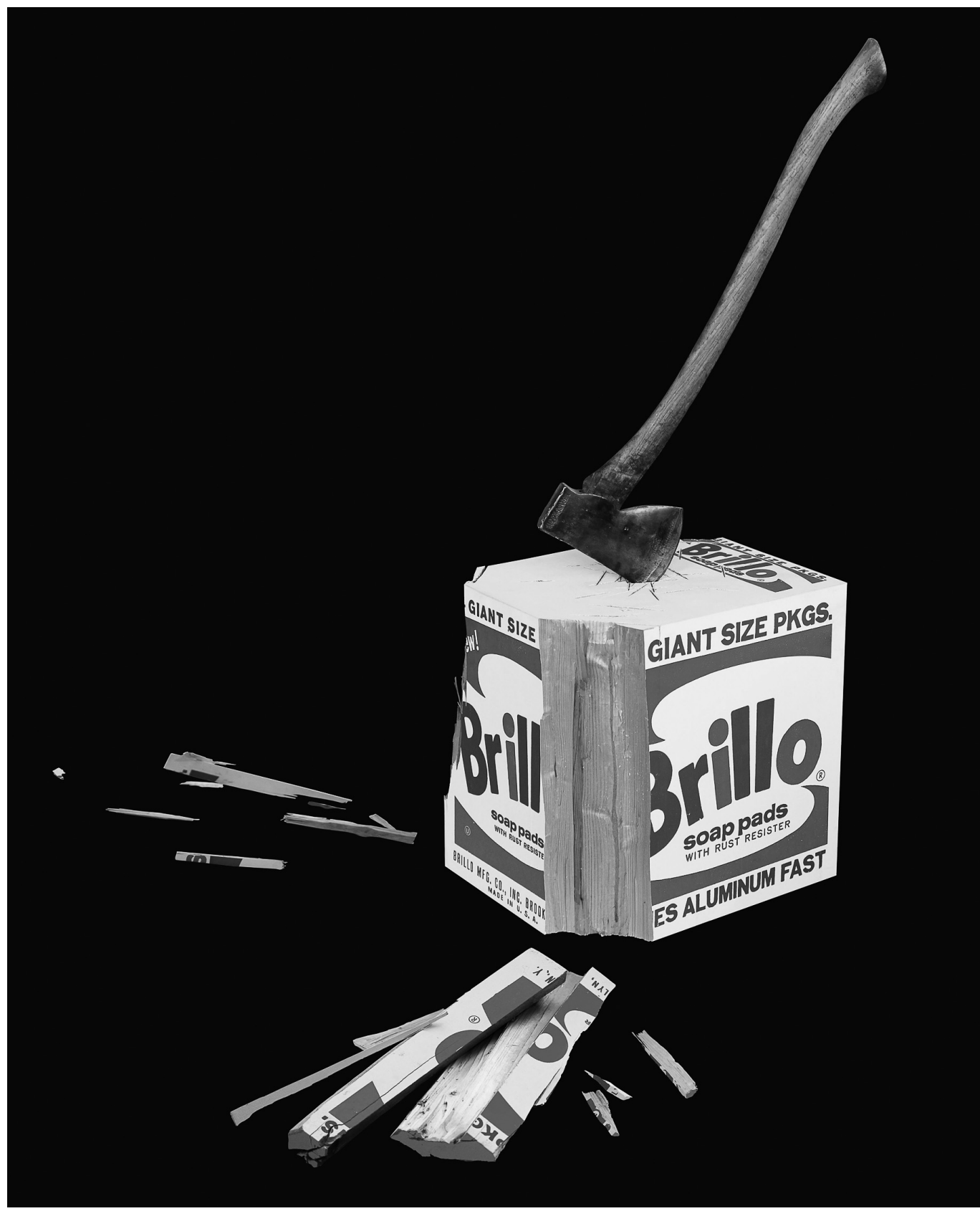

Charles Lutz, Memento Mori, 2011. @ 2011 Charles Lutz. 


\section{Notes}

1. This is seen in Hans Belting's near-apocalyptic view in The End of the History of Art? (Chicago: Chicago University Press, 1997, originally in German, 1984). It is argued that it is impossible to perceive recent developments in the arts in terms of progress. That same year, 1984, Danto presented a similar view. My reflections are deeply indebted to the stimulus of Danto's work. His philosophy of art changed the whole mind-set of good analytic philosophy of art. As philosopher and as critic - he belongs to history. Danto's article "The End of Art" is in The Death of Art, edited by Berel Lang (New York: Haven Publications, 1984), 5-35.

2. After the End of Art: Contemporary Art and the Pale of History (Princeton: Princeton University Press, 1997); The Philosophical Disenfranchisement of Art (New York: Columbia University Press, 1986); The State of the Art (New York: Prentice Hall Press, 1987); Beyond the Brillo Box; The Visual Arts in Post-Historical Perspective (New York: Farrar, Straus, and Giroux, 1992); The Madonna of the Future: Essays in a Pluralistic Art World (New York: Farrar, Straus, and Giroux, 2000); Unnatural Wonders: Essays from the Gap Between Art and Life (New York: Farrar, Straus, and Giroux, 2005); "The End of Art: A Philosophical Defence", History and Theory 37 (1998), no. 4, 127-43.

3. E. Geulen, The End of Art: Rereadings in a Rumor after Hegel (Stanford: Stanford University Press, 2006).

4. Hegel's Aesthetics: Lectures on Fine Art, trans. T. M. Knox (Oxford: The Clarendon Press, 1975), 10.

5. Ibid., 2.

6. C. L. Carter, "Hegel and Danto on the End of Art", February 16, 2008. Collected from www.aesthetics.com.cn/s4oc1139.aspx, 1; See also L. Krukowski, "Hegel, 'Progress', and the Avant-garde", Journal of Art and Art Criticism 44 (1986), no. 3, 279-90; B. Hilmer, "Being Hegelian after Danto", History and Theory 37 (1998), no. 4, 71-86; K. Harris, "Hegel and the Future of Art", The Review of Metaphysics 27 (1974), no. 4, 677-96. See also Hegel's Aesthetics, 3-7.

7. Hegel's theory need not be seen as a thesis about art so much as a thesis regarding our relationship to it (his piece ends on a positive note, with art passing over the definition of art into philosophy). All in all, art invites intellectual considerations for purposes of knowing philosophically what art is.

8. See David Bourdon, Warhol (New York: Harry N. Abrams,1995), 186.

9. Arthur C. Danto, "The Artworld”, Originally published 1964, reprinted in Aesthetics and the Philosophy of Art: The Analytic Tradition. eds. P. Lamarque and Stein Haugom Olsen (Oxford: Blackwell, 2004), 32.

10. Symptoms often seem combined, and some appear more dire than others. But behind all these is the contemporary extension of the cultural scene: the market becomes a determiner of artistic value. Donald Kuspit writes "Art may be 
indeterminate, but money has the power to determine what is art", The End of Art (2005), 21; the rise of a manifold of artistic genres: performance, installations, conceptual art, jazz and popular music, political art, and the combination of them; Joseph Kosuth writes "objects are conceptually irrelevant to the condition of art”, Art after Philosophy and After (1991), 26. Important facts are the increase of mechanical reproduction in the process of distributing art; the lack of unified progression and critical criteria; the difficulty of determining a sense of progression to contemporary art. No one reads more than a tiny fraction of texts about artworks, in catalogues or periodicals, blogs and websites that announce new art, and no one reads more than a few of the hundreds of books on art history and aesthetics that appear each year. The evaluation of this new and contemporary art differs, of course, because much is pure entertainment but might thereby say something important about our experience of cultural productions today.

11. After the End of Art: Contemporary Art and the Pale of History (Princeton: Princeton University Press, 1997), 4.

12. James Harvey (1929-1965), an unknown abstract expressionist who, in his day job, designed, among other products, the Brillo boxes that Warhol later made replicas of. Harvey regarded pop art with distaste and distinguished between different processes of making commercial and high art products. So, what's one man's box (Harvey), may be another man's art (Warhol). Picture 1 shows one of the few surviving examples of Harvey's box. It is owned by the art historian Irving Sandler, who keeps it in his Manhattan apartment encased in Plexiglas.

13. Andy Warhol (1928-1987): Brillo Box (Soap Pads), 1964. New York, Museum of Modern Art (MoMA). Synthetic polymer paint and silkscreen on wood, 17 $1 / 8 \times 17 \times 14^{\prime \prime}(43.5 \times 43.2 \times 36.5 \mathrm{~cm})$. Gift of Doris and Donald Fisher. Acc. nn.: 357.1997. (C) 2012. Digital image, The Museum of Modern Art, New York/Scala, Florence

14. Marcel Duchamp's ready-mades such as Fountain (1917) problematizes aesthetic theories of art and the importance that the intentional context has on the status of art. Andy Warhol's Brillo box (1964) takes up the thread originated with Duchamp's experiments with ready-mades (that cannot then be viewed as part of developmental art history).

15. The Philosophical Disenfranchisement of Art (New York: Columbia University Press, 1986), 111.

16. Some of the most ground-breaking research being done in the field of art history includes the heralding of art by women, minorities, and other undervalued areas of research.

17. Danto writes in Encounters and Reflections: Art in the Historical Present (Berkeley: University of California Press, 1990), that we live in a time where "there are no outward criteria any longer of what can be a work of art" (8). But 
this is only to point out the lesson of indiscernibles and the immaterial factor as intention when solving through philosophy the ontological question posed by art.

18. Colin Blackstock, "Cleaner clears up Hirst's ashtray art", The Guardian, Friday 19 October 2001.

19. Damien Hirst (b. 1965): Home Sweet Home, 1996. New York, Museum of Modern Art (MoMA). Multiple of screenprint on porcelain, object: $83 / 8 \times 83 / 8$ $\times 15 / 16$ " $(21.2 \times 21.2 \times 2.4 \mathrm{~cm})$. Publisher: Gagosian Gallery, New York, New York. Printer: Swid Powell, New York. Edition: 1,500. The Associates Fund. Inv. n.: 261.2006. (C) 2012. Digital image, The Museum of Modern Art, New York/Scala, Florence.

20. A. C. Danto, The Transfiguration of the Commonplace (Cambridge: Harvard University Press, 1981), 135.

21. The story of art's historical development is not a story at all but an object of hegemonic struggle. The very idea of a single, uncontested homogenous history has withered under the strain of several politicizing assaults on art history as a discipline and as an object of study. In the absence of such narrative, it follows that there is nothing to end.

22. N. Carroll, "Danto's New Definition of Art and the Problem of Art Theories", British Journal of Aesthetics 37 (1997), no. 4, 386-92.

23. A. C. Danto, The Philosophical Disenfranchisement of Art (New York: Columbia University Press, 1986), 115.

24. A.C. Danto, "The Artworld", The Journal of Philosophy 61 (1964), reprinted in Aesthetics and the Philosophy of Art: The Analytic Tradition, eds. Peter Lamarque and Stein Haugom Olsen (Oxford: Blackwell, 2004), 33.

25. Thanks to Charles Lutz, Johanna McElwee, Susanna Mälarstedt, Jacob Lund for different involvements in making this article, and to an anonymous referee for useful comments on an earlier draft of this article. 